\title{
Estimation of Excess Life Cancer Risk and Annual Effective Dose For Boreholes and Well Water in Dutse, Jigawa State Nigeria.
}

\author{
Dankawu UM ${ }^{1 *}$, HY Shuaibu' ${ }^{1}$, MN Maharaz ${ }^{1}$, T. Zangina' ${ }^{1}$ FM Lariski ${ }^{4}$, M. Ahmadu ${ }^{2}$, SS \\ Zarma', JN Benedict, M. Uzair ${ }^{3}$ G.D Adamu', and A. Yakubu ${ }^{1}$ \\ 'Department of Physics, \\ Federal University Dutse, \\ P.M.B, 7156, \\ Jigawa State, \\ Nigeria. \\ ${ }^{2}$ Department of Chemistry, \\ Federal University Dutse, \\ P.M.B, 7156, \\ Jigawa State, \\ Nigeria. \\ ${ }^{3}$ Department of Physics
Sule Lamido University Kafin Hausa,
Jigawa State Nigeria \\ ${ }^{4}$ Department of Physics \\ Yobe State University,
}

Damaturu

\begin{abstract}
The level of ${ }^{222} R n$ concentration for water samples collected from twenty-two (22) water samples in Dutse Local Government, Jigawa State, Nigeria was determined using liquid scintillation counter (Model: Tri-CarbLSA1000). Borehole and local hand dug wells are the two sources of water been collected. Also, an attempt was made to estimate the Excess Life Cancer Risk and Annual Effective Dose due to Ingestion for different ages groups. The mean value of ${ }^{222 R n}$ concentration were found to be 82.7461 and $94.10771 \mathrm{BqL}-1$ for boreholes and well water samples respectively. All the mean values are above the maximum concentration level set by UNSCEAR; WHO, but below European commission of $100 \mathrm{BqL} \mathrm{L}^{-1}$. The resulting mean annual effective doses due to ingestion of radon in the water samples for infants, children and adults, were1.057081 and $1.202226 \mathrm{mSvy}^{-1}, 0.90607$ and $1.030479 \mathrm{mSvy}^{-1}$ and 0.604047 and $0.686986 \mathrm{mSvy}^{-1}$, respectively. Also, the resulting mean Excess life cancer risk due to ingestion in borehole and well water sample for adults, children and infants were $2.114 E-3$ and $2.37 \mathrm{E}$ 1, 3.171 $\times 10^{-3}$ and 3.61 E-3 and 3.7 E-4 and $4.21 \mathrm{E}-3$ respectively. All the values were found to be above the maximum concentration level for drinking water and domestic purposes. as set by UNSCEAR, WHO, EU and USEPA. From the radiological point of view, this study indicates that water resources around Dutse Local Government Area Jigawa State were not safe for domestic purposes and drinking.
\end{abstract}

Keywords: ${ }^{222} \mathrm{Rn}$ Concentration, Annual Effective Dose, Excess Life Cancer Risk, Ingestion, liquid scintillation counter. 


\section{INTRODUCTION}

Water is a crucial resource for the existence and survival of mankind and the importance of good quality drinking water cannot be over emphasized (Chifu et al 2016). A large portion of the world's population depends on groundwater (i.e. wells, bore holes) for their survival. (Nnaji et.al, 2019). Water been vital and, concurrently, one of the most abundant and important natural resources. The Earth's surface is covered with almost $70 \%$ of the water, which is approximately estimated at a volume of 1.4 billion $\mathrm{km}$. (Nwankwo, 2013). Borehole water and well water are the most abundant and important freshwater resource for man. Political, Economic and Social, development has been largely related to the distribution and availability of freshwaters contained in riverine systems (Joseph, 2016). Water quality problems have intensified through the ages in response to the industrial centers and increasing growth of populations. Polluted water is an important vehicle for the spread of diseases. 1.8 million people In developing countries, mostly children, are die every year as a result of related diseases in water (WHO, 2004; Simon, et.al, 2011). Water pollution arises as a result of materials used such as fertilizers by farmers, hospital, and rivers by industries and also sewage and waste disposal into the environment. All these disposed materials often contain radio nuclides (Shitu et.al, 2016). Water is crucial not only for socio-economic development of a country but also for sustaining life. (Chifu et al 2016). However, the availability good quality drinking water remains a great challenge. Groundwater is currently one of the major sources of water in Dutse local government area Jigawa state, Nigeria and its environs. (Joseph, 2016).

Naturally occurring ${ }^{222} \mathrm{Rn}$, which belong to the ${ }^{238} \mathrm{U}$ decay-series, are inert gas and thus found at underground spaces and highly enriched level in ground waters. Since radon and its daughters produce many beta and alpha particles, its ingestion and inhalation can cause cancers in human organs, more especially in the lungs and stomach. Thus, assessing radon in air, in addition to that in water, is an important step in reducing potential exposure to it. Also, ${ }^{222} \mathrm{Rn}$ has been used as an excellent tool for geophysical processes and tracing many environmental such as gas exchange across the air sea surface. (Jong et.al, 2006).

${ }^{222} \mathrm{Rn}$ is the most abundant and stable isotope of radon with half-life of 3.8 days. It creates radioactive daughters and decays by emitting an alpha particle of $5.49 \mathrm{meV}$. In terms of nature, radon is soluble in all the water sources on the Earth including underground waters, lakes, springs, oceans, rivers springs and even in atmospheric precipitation (Khattak, et.al, 2011). Radon being a player of a dual role in man's life. On other hand its presence in rocks soil and waters has greatly predicted volcanic activities, the earthquake occurrence, and fault dislocation and in hydrological research, also its presence in drinking water and high level in indoor environment constitutes a major health hazard for mankind due to its carcinogenic effects. (Khattak, et.al, 2011). In developing countries including Nigeria, lack of safe drinking water is one of the serious threats to the human health. However, borehole, streams, well and rivers waters are often used as alternative to the scarce pipe-borne water for domestic activities and drinking without undergoing any treatment (Dankawu et al 2021).

So many works have been carried out on determination of radon and estimated annual effective dose in drinking water within and outside Nigeria. However, there is little data recorded on radon in Dutse Local Government Jigawa State Nigeria. This is due to the fact that determination of radon is done without estimation of excess lifetime cancer risk and annual effective dose. The main aim of this study was to estimate the Excess Life Cancer Risk and Annual Effective Dose due to ingestion for some boreholes and well water in Dutse Local Government Jigawa State, Nigeria. The study has the following specific objectives: to examine 
the radon concentration, the annual effective dose due to ingestion for different age catogories (Adults, Children's and Infants). and excess lifetime cancer risk.

\section{MATERIALS AND METHODS}

\section{Study Area}

Dutse Local Government Area, one of the seven Local Government in Dutse emirate Jigawa state Nigeria. It is located between Latitudes $11^{\circ} 38^{\prime} 31^{\prime \prime} \mathrm{N}$ and $11^{\circ} 46^{\prime} 16^{\prime \prime} \mathrm{N}$ and longitudes 9018' 33"E and 9024' 24'E. According to the 2006 census, Dutse has a population of 251,135, people living in the area, with 125,773 male and 125,362 females (NPC, 2006). The climate of Dutse is tropical wet dry climate (Koppen AW) classification and the temperature is warm to hot almost throughout the year, with slightly cool period around November through February. The mean annual temperature is $26^{\circ} \mathrm{C}$ but, the monthly mean value were ranges between $21^{\circ} \mathrm{C}$ during coldest months (December/February) and $31^{\circ} \mathrm{C}$ during hottest months (April/May) (Aminu, 2015).

\section{Sample Collection}

A total of twenty-two (22) samples water were collected in eleven different wards under Dutse local government Area. Two sample from each ward, (one sample for both local wells and boreholes), making eleven sample for both local wells and boreholes from different parts of Dutse local government Area respectively. All the water sample were obtained during dry season, the sample were collected with a cleaned $750 \mathrm{ml}$ plastic bottles and ${ }^{222} \mathrm{Rn}$ concentration analyzed. The sample containers were rinsed three times with distilled water after been cleaned with detergent solutions to avoid contamination. For boreholes sources, the samples were collected after turning on and allowing free flow of water for over five minutes. This was to enable the water temperature to stabilize and also to purge any air that might have been trapped within the pressure line. The well samples were collected with the aid of bailers. The bottles were filled to the brim to prevent the occurrence of air bubbles in them. The samples were then labeled carefully indicating the location, time and date of collection. The samples were taken to the laboratory within the shortest possible time in order to reduce the decay coefficient. For all the samples, analysis was done before the elapse of the maximum holding time of 3days, thereby ruling out the need of any preservation (Abba et al, 2020).

\section{Sample Preparation}

$10 \mathrm{ml}$ each sample were transferred into a $20 \mathrm{ml}$ glass scintillation vial to which $10 \mathrm{ml}$ of instagel scintillation cocktail is added. Having been tightly sealed, to extract the ${ }^{222} \mathrm{Rn}$ in water phase into the organic scintillate, the vials were shaken for at least two minutes and the collected samples were then counted for 60minutes in a liquid scintillation counter (Dankawu et al, 2021).

\section{Sample Analysis}

Liquid Scintillation Counter (Tri-Carb LSA 1000TR) model located at the Centre for Energy Research and Training (CERT), Ahmadu Bello University, Zaria - Nigeria. Were used to analyzed the prepared samples after they were allowed to stay for almost three-four hours in order to attained the equilibrium between ${ }^{222} \mathrm{Rn}$ and its daughter progeny.

The ${ }^{222} \mathrm{Rn}$ concentration in local wells and boreholes water sample were determined using equation 1. (Dankawu et.al. 2021)

$\operatorname{Rn}\left(\frac{\mathrm{Bq}}{\mathrm{L}}\right)=\frac{100 \times\left(R_{n} \times R_{0}\right) \exp (\lambda \mathrm{t})}{60 \times 5 \times 0.964}$ 
where $\mathrm{Rn}(\mathrm{Bq} / \mathrm{L})={ }^{222} \mathrm{Rn}$ concentration in $\left(\mathrm{BqL}^{-1}\right), \mathrm{R}_{\mathrm{n}}=$ sample total count rate (count $\left.\mathrm{min}^{-1}\right), \lambda$ $={ }^{222} \mathrm{Rn}$ decay factor $\left(1.26 \times 10^{-4} \mathrm{~min}^{-1}\right), R_{\mathrm{O}}=$ background count rate $\left(\right.$ count $\left.\mathrm{min}^{-1}\right), \mathrm{t}=$ elapsed time (3days), 100 is a conversion factor from per $10 \mathrm{ml}$ to per liter $\left(1^{-1}\right), 5$ is the number of emissions per count; and $0.964=$ fraction of ${ }^{222} \mathrm{Rn}$ in the cocktail in a vial of $22 \mathrm{ml}$ total. The annual effective dose of ${ }^{222} \mathrm{Rn}$ through drinking water, was calculated using equation 2. (Abba et.al. 2020)

$\mathrm{E}=\mathrm{K} \times \mathrm{G} \times \mathrm{C} \times 1000$

where $\mathrm{E}$ is the annual effective dose $\left(\mathrm{mSvy}^{-1}\right), \mathrm{C}$ is the ${ }^{222} \mathrm{Rn}$ concentration in water $(\mathrm{Bq} / \mathrm{L}), \mathrm{G}$ is the water ingestion rate $(182.5 \mathrm{~L} / \mathrm{Y}, 547.5 \mathrm{~L} / \mathrm{Y}$ and730 L/Y) for infants, children and adults respectively (UNSCEAR, 1993). $\mathrm{K}$ is the dose coefficient $\left(7 \times 10^{-8}, 2 \times 10^{-8}\right.$, and10-8) for infants, children and adult (UNSCEAR, 2000). and 1000 is the conversion coefficient from Sv to mSv. and Excess life cancer risk (ELCR) due to ingestion for different age categories was calculated from annual effective dose using equation 3 (Adamoh et.al 2021).

$\mathrm{ELCR}=\mathrm{AEDE} \times \mathrm{DL} \times \mathrm{RF}$

Where $\mathrm{AEDE}=$ annual effective dose $\mathrm{mSv} / \mathrm{y}, \mathrm{DL}=$ life expectancy $(70$ years $)$ and $\mathrm{RF}=$ fatal risk factor per Sievert (S/v). In case of stochastic effects, ICRP-60 uses RF of 0.05 for the public

\section{RESULTS}

Table 1: ${ }^{222} \mathrm{Rn}$ Concentrations ( $\left.\mathrm{BqL}^{-1}\right)$ and Annual Effective Dose Due to Ingestion for Different Age Groups (Adult, Children and Infant) in $\mathrm{mSvy}^{-1}$ for borehole Water Sample.

\begin{tabular}{|c|c|c|c|c|c|c|}
\hline Sample ID & Latitude & Longitude & $\begin{array}{c}\text { 2222Rn Conc. } \\
\left(\mathrm{BqL}^{-1}\right)\end{array}$ & $\begin{array}{c}\mathrm{E}_{\mathrm{A}} \text { ing } \\
(\mathrm{mSvy}-1)\end{array}$ & $\begin{array}{c}\text { E }_{\text {Cing }} \\
\left(\mathrm{mSvy}^{-1}\right)\end{array}$ & 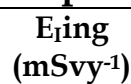 \\
\hline UMD 1 & N 115ㄴ'53.39" & E 9०23'21.92" & 46.03 & 0.34 & 0.50 & 0.59 \\
\hline UMD 2 & 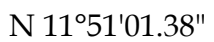 & E $9^{\circ} 15^{\prime} 40.16^{\prime \prime}$ & 38.53 & 0.28 & 0.42 & 0.49 \\
\hline UMD 3 & N 115ㅇ'48.79" & E $9^{\circ} 12^{\prime} 09.96^{\prime \prime}$ & 74.68 & 0.55 & 0.82 & 0.95 \\
\hline UMD 4 & N 11운'32.69" & E $9^{\circ} 19^{\prime} 04.88^{\prime \prime}$ & 273.22 & 1.99 & 2.99 & 3.49 \\
\hline UMD 5 & N $11^{\circ} 41^{\prime} 04.92^{\prime \prime}$ & E $9^{\circ} 14 ' 39.68^{\prime \prime}$ & 75.44 & 0.55 & 0.83 & 0.96 \\
\hline UMD 6 & N 11욱' $55.95^{\prime \prime}$ & Е $9^{\circ} 20^{\prime} 49.56^{\prime \prime}$ & 131.24 & 0.96 & 1.44 & 1.68 \\
\hline UMD 7 & N $11^{\circ} 40^{\prime} 17.02^{\prime \prime}$ & E $9^{\circ} 24^{\prime} 41.53^{\prime \prime}$ & 32.21 & 0.24 & 0.35 & 0.41 \\
\hline UMD 8 & N $11^{\circ} 43^{\prime} 32.13^{\prime \prime}$ & E 9०20'39.24" & 31.23 & 0.23 & 0.34 & 0.40 \\
\hline UMD 9 & N $11^{\circ} 44^{\prime} 59.03^{\prime \prime}$ & E $9^{\circ} 20^{\prime} 30.44^{\prime \prime}$ & 71.19 & 0.52 & 0.78 & 0.91 \\
\hline UMD 10 & N 114''19.84" & E $9^{\circ} 19^{\prime} 01.78^{\prime \prime}$ & 33.84 & 0.25 & 0.37 & 0.43 \\
\hline UMD 11 & N 115ㅇ'41.41" & E $9^{\circ} 18^{\prime} 21.09^{\prime \prime}$ & 102.6 & 0.75 & 1.12 & 1.31 \\
\hline Mean & & & 82.75 & 0.60 & 0.91 & 1.06 \\
\hline
\end{tabular}

${ }^{222} \mathrm{Rn}$ concentrations $\left(\mathrm{BqL}^{-1}\right)$ and annual effective dose due to ingestion for different age groups (adult, children and infant). (mSvy-1) for borehole water sample. Annual effective dose from ingestion for Adult in borehole water sample were found to be in the range of $0.23 \mathrm{mSvy}^{-1}$ as the lowest value obtained from UM 8 to $1.99 \mathrm{mSvy}^{-1}$ as the highest value obtained from UM 4 with the mean value of $0.60 \mathrm{mSvy}^{-1}$. The annual effective dose due to ingestion for children in borehole water sample were found to be in the range of $0.34 \mathrm{mSvy}^{-1}$ as the lowest value obtained from UM 8 to $2.99 \mathrm{mSvy}^{-1}$ as the highest value obtained from UM 4 with the mean value of $0.91 \mathrm{mSvy}^{-1}$ and the annual effective dose due to ingestion for infant in borehole water sample were found to be in the range of $0.40 \mathrm{mSvy}^{-1}$ as the lowest value obtained from UM 8 to $3.49 \mathrm{mSvy}^{-1}$ as the highest value obtained from UM 4 with the mean value of $1.06 \mathrm{mSvy}^{-1}$. 
Fig 1. Chart showing the Annual Effective Dose due to Ingestion for different age groups (Adult, Children and Infant). (mSvy ${ }^{-1}$ ) for Borehole Water Sample.
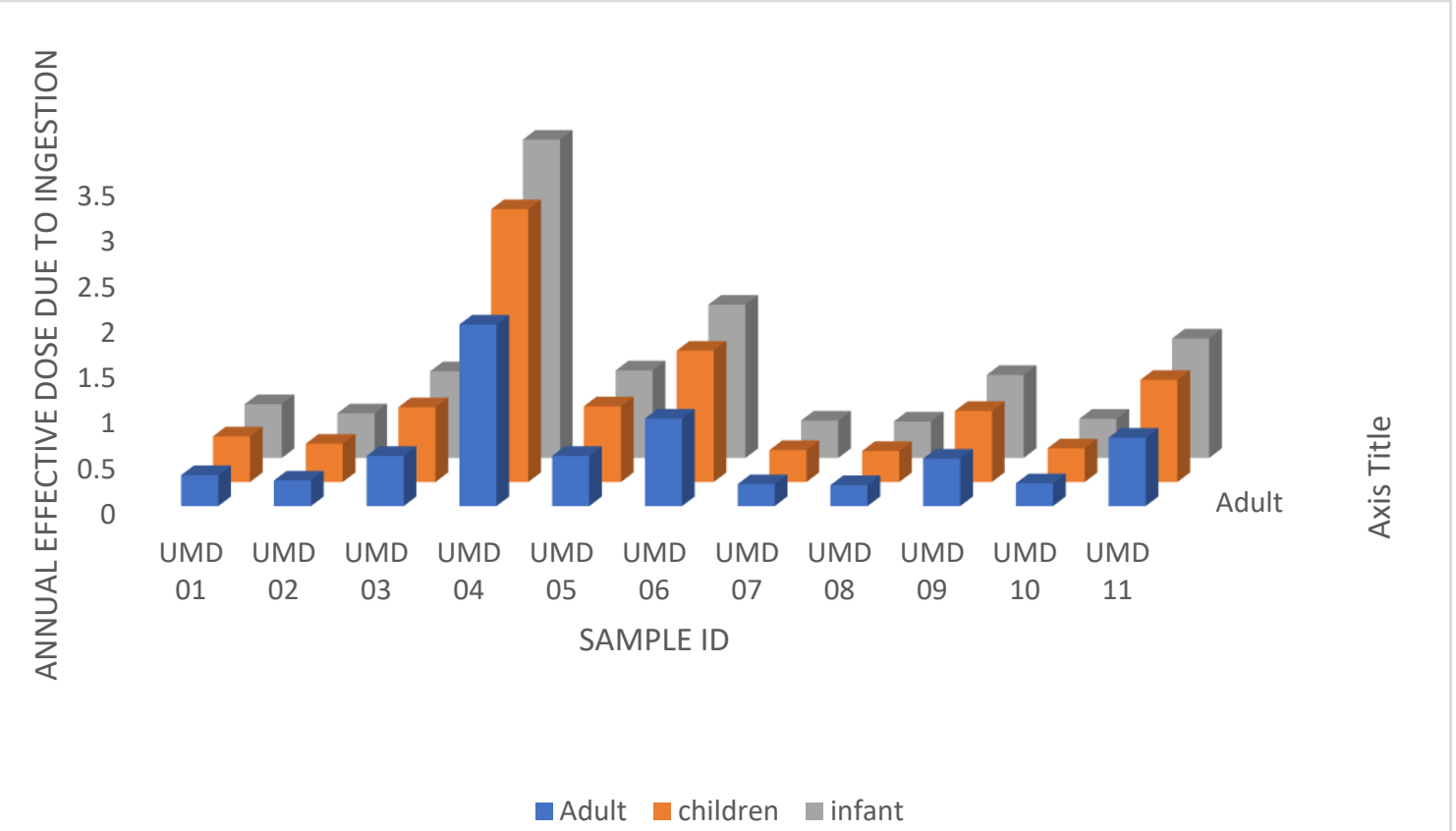

Fig. 1. Annual Effective Dose due to Ingestion for different age groups (Adult, Children and Infant). (mSvy $\left.{ }^{-1}\right)$ for Borehole Water Sample.

Table 2 and Fig. 2 present ${ }^{222} \mathrm{Rn}$ concentrations $\left(\mathrm{BqL}^{-1}\right)$ and annual effective dose for different age categories (Adult, children and infant). $\left(\mathrm{mSvy}^{-1}\right)$ for local hand-dug well water sample.

Table 2: ${ }^{222} \mathrm{Rn}$ Concentrations $\left(\mathrm{BqL}^{-1}\right)$ and Annual Effective Dose Due to Ingestion for Different Age Groups (Adult, Children and Infant). (mSvY-1) for Local Hand-Dug Well Water Sample.

\begin{tabular}{|c|c|c|c|c|c|c|}
\hline $\begin{array}{l}\text { Sample } \\
\text { ID }\end{array}$ & Latitude & Longitude & $\begin{array}{l}{ }^{222 R n} \text { Conc. } \\
\left(\mathrm{BqL}^{-1}\right)\end{array}$ & $\begin{array}{l}\text { E }_{\mathrm{A}} \text { ing } \\
\text { (mSvY-1) }\end{array}$ & $\begin{array}{l}E_{\text {Cing }} \\
\left(m S v Y^{-1}\right)\end{array}$ & $\begin{array}{l}\text { E }_{\text {Iing }} \\
\text { (mSvY-1) }\end{array}$ \\
\hline UMD 12 & N 1200'28.14" & E 9०21'25.17" & 39.96 & 0.29 & 0.44 & 0.51 \\
\hline UMD 13 & N 1149'17.31" & E $9^{\circ} 15^{\prime} 43.96^{\prime \prime}$ & 48.81 & 0.36 & 0.53 & 0.62 \\
\hline UMD 14 & N 1150'50.06" & E $9^{\circ} 10^{\prime} 40.66^{\prime \prime}$ & 155.94 & 1.14 & 1.71 & 1.99 \\
\hline UMD 15 & N 11여'15.78" & E 9¹9'50.91" & 252.46 & 1.84 & 2.76 & 3.23 \\
\hline UMD 16 & N 1141'11.58" & E $9^{\circ} 15^{\prime} 24.74^{\prime \prime}$ & 119.37 & 0.87 & 1.31 & 1.52 \\
\hline UMD 17 & N 114ㅇ'43.63" & E 9०20'13.39" & 81.64 & 0.60 & 0.89 & 1.04 \\
\hline UMD 18 & N 1141'42.09" & E 9²3'11.31" & 47.23 & 0.34 & 0.52 & 0.60 \\
\hline UMD 19 & N $11^{\circ} 41^{\prime} 05.63^{\prime \prime}$ & Е $9^{\circ} 21^{\prime} 04.86^{\prime \prime}$ & 77.14 & 0.56 & 0.84 & 0.99 \\
\hline UMD 20 & N 11ํ4' $18.08^{\prime \prime}$ & E $9^{\circ} 20^{\prime} 53.33^{\prime \prime}$ & 75.88 & 0.55 & 0.83 & 0.97 \\
\hline UMD 21 & N $11^{\circ} 44^{\prime} 54.06^{\prime \prime}$ & Е 9०13'39.46" & 32.69 & 0.24 & 0.36 & 0.42 \\
\hline UMD 22 & N 1150'57.06" & E $9^{\circ} 18^{\prime} 36.49^{\prime \prime}$ & 104.06 & 0.76 & 1.14 & 1.33 \\
\hline Mean & & & 94.11 & 0.69 & 1.03 & 1.20 \\
\hline
\end{tabular}

The annual effective dose from ingestion for Adult in local hand-dug well water sample, were found to be in the range of $0.24 \mathrm{mSvy}^{-1}$ as the lowest value obtained from UM 21 to $1.84 \mathrm{mSvy}^{-}$ 1 as the highest value obtained from UM 15 with the mean value of $0.69 \mathrm{mSvY}^{-1}$, and the annual effective dose due to ingestion for children in local hand-dug well water sample were found to be in the range of $0.36 \mathrm{mSvy}^{-1}$ as the lowest value obtained from UM 21 to $2.76 \mathrm{mSvy}^{-1}$ as the highest value obtained from UM 15 with the average value of $1.03 \mathrm{mSvy}^{-1}$ and the annual 
effective dose due to ingestion for Infant in local hand-dug well water sample were found to be in the range of $0.42 \mathrm{mSvy}^{-1}$ as the lowest value obtained from UM 21 to $3.23 \mathrm{mSvY}^{-1}$ as the highest value obtained from UM 15 with the mean value of $1.20 \mathrm{mSvy}^{-1}$

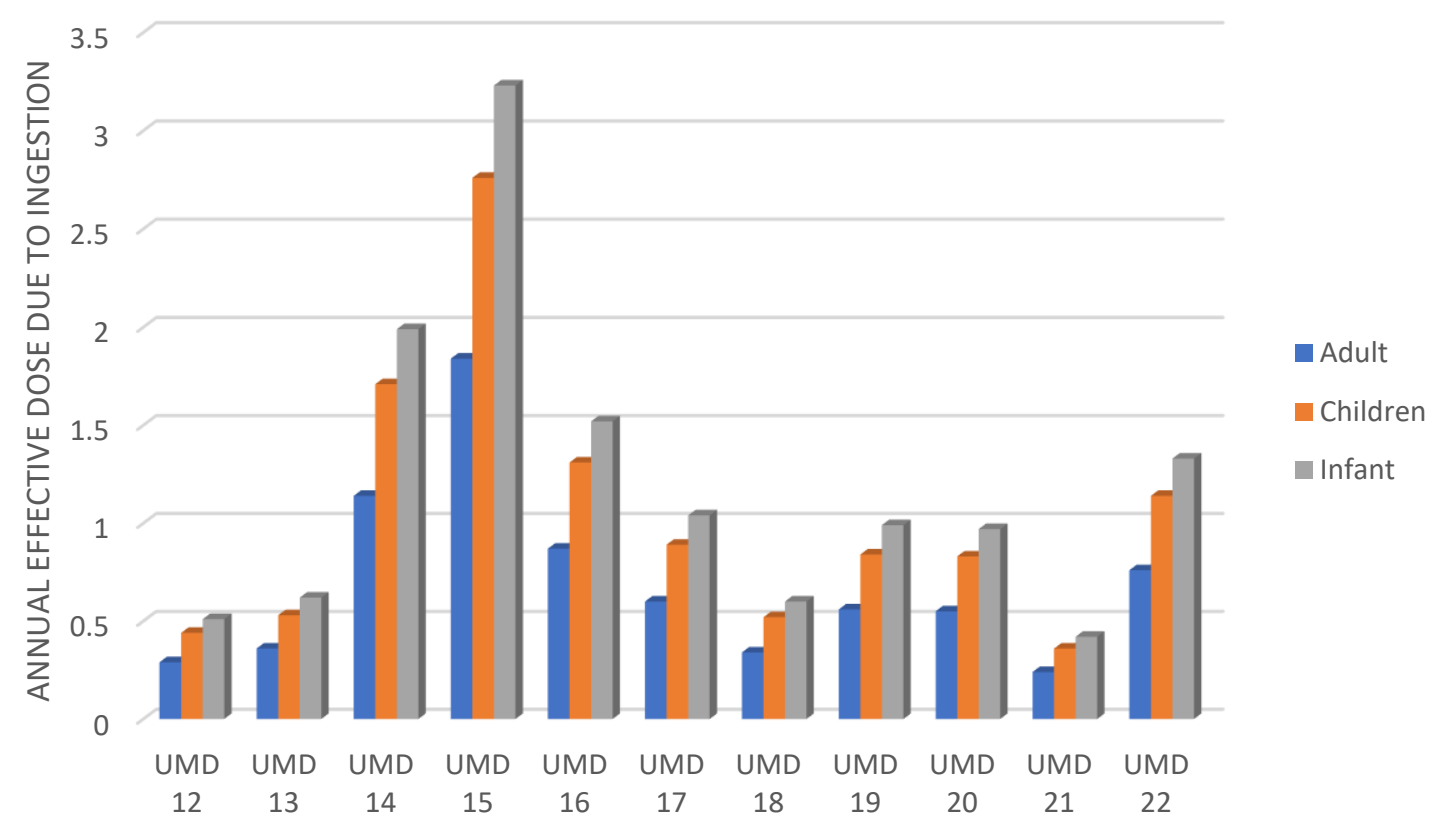

Fig 2. Annual Effective Dose for different age categories (Adult, Children and Infant). (msvy-1) for local handdug Well Water Sample.

Table 3 shows the result of excess life cancer risk from annual effective dose from ingestion for infant infant, children and infant in borehole water sample.

Table:3. Excess Life Cancer Risk (ELCR) due to Ingestion for Different Age Categories (Adult, Children and Infant) for Borehole Water Sample.

\begin{tabular}{llll}
\hline Sample ID & Adult & Children & Infant \\
\hline UMD 1 & $1.18 \mathrm{E}-3$ & $1.76 \mathrm{E}-3$ & $2.06 \mathrm{E}-3$ \\
UMD 2 & $9.84 \mathrm{E}-4$ & $1.48 \mathrm{E}-3$ & $1.72 \mathrm{E}-3$ \\
UMD 3 & $1.91 \mathrm{E}-3$ & $2.86 \mathrm{E}-3$ & $3.34 \mathrm{E}-3$ \\
UMD 4 & $6.98 \mathrm{E}-3$ & $1.05 \mathrm{E}-2$ & $1.22 \mathrm{E}-2$ \\
UMD 5 & $1.93 \mathrm{E}-3$ & $2.89 \mathrm{E}-3$ & $3.37 \mathrm{E}-3$ \\
UMD 6 & $3.35 \mathrm{E}-3$ & $5.03 \mathrm{E}-3$ & $5.87 \mathrm{E}-3$ \\
UMD 7 & $1.24 \mathrm{E}-3$ & $1.44 \mathrm{E}-3$ \\
UMD 8 & $8.23 \mathrm{E}-4$ & $1.20 \mathrm{E}-3$ & $1.40 \mathrm{E}-3$ \\
UMD 9 & $7.98 \mathrm{E}-4$ & $2.73 \mathrm{E}-3$ & $3.18 \mathrm{E}-3$ \\
UMD 10 & $1.82 \mathrm{E}-3$ & $1.30 \mathrm{E}-3$ & $1.51 \mathrm{E}-3$ \\
UMD 11 & $8.65 \mathrm{E}-4$ & $3.93 \mathrm{E}-3$ & $4.59 \mathrm{E}-3$ \\
\hline Mean & $2.62 \mathrm{E}-3$ & $3.17 \mathrm{E}-3$ & $3.7 \mathrm{E}-4$ \\
\hline
\end{tabular}

It was found that for adult the excess life cancer risk for borehole water sample varies from 7.98E-4 for sample point UM 8 as the lowest value to 6.98E-3 for sample UM 4 as the highest values with mean value of 2.11E-3, For children, the excess life cancer risk for borehole water sample varies from 1.20E-3 for sample point UM 8 as the lowest value to $1.05 \mathrm{E}-2$ for sample UM 4 as the highest values with mean value of 3.17E-3 and for infant the excess life cancer 
risk for borehole water sample varies from $1.40 \mathrm{E}-3$ for sample point UM 8 as the lowest value to $1.22 \mathrm{E}-2$ for sample UM 4 as the highest values with mean value of 3.7E-4.

Table 4. Revealed the result of excess life cancer risk from annual effective dose from ingestion for Adult, Children and Infant were estimated for local hand-dug wells water sample.

Table:4. Excess Life Cancer Risk (ELCR) due to Inhalation and Ingestion for Different Age Categories (Adult, Children and Infant) for Local Hand-Dug Wells Water Sample.

\begin{tabular}{llll}
\hline Sample ID & Adults & Children & Infant \\
\hline UMD 12 & $1.02 \mathrm{E}-3$ & $1.53 \mathrm{E}-3$ & $1.79 \mathrm{E}-3$ \\
UMD 13 & $1.25 \mathrm{E}-3$ & $1.87 \mathrm{E}-3$ & $2.18 \mathrm{E}-3$ \\
UMD 14 & $3.98 \mathrm{E}-3$ & $5.98 \mathrm{E}-3$ & $6.97 \mathrm{E}-3$ \\
UMD 15 & $6.45 \mathrm{E}-3$ & $9.68 \mathrm{E}-3$ & $1.13 \mathrm{E}-2$ \\
UMD 16 & $3.05 \mathrm{E}-3$ & $4.58 \mathrm{E}-3$ & $5.34 \mathrm{E}-3$ \\
UMD 17 & $2.09 \mathrm{E}-3$ & $3.13 \mathrm{E}-3$ & $3.65 \mathrm{E}-3$ \\
UMD 18 & $1.21 \mathrm{E}-3$ & $1.81 \mathrm{E}-3$ & $2.11 \mathrm{E}-3$ \\
UMD 19 & $1.97 \mathrm{E}-3$ & $2.96 \mathrm{E}-3$ & $3.45 \mathrm{E}-3$ \\
UMD 20 & $1.94 \mathrm{E}-3$ & $2.91 \mathrm{E}-3$ & $3.39 \mathrm{E}-3$ \\
UMD 21 & $8.35 \mathrm{E}-3$ & $1.25 \mathrm{E}-3$ & $1.46 \mathrm{E}-3$ \\
UMD 22 & 0.003 & $3.99 \mathrm{E}-3$ & $4.65 \mathrm{E}-3$ \\
\hline Mean & $2.37 \mathrm{E}-1$ & $3.61 \mathrm{E}-3$ & $4.21 \mathrm{E}-3$ \\
\hline
\end{tabular}

Excess life cancer risk from annual effective dose from ingestion for Adult, Children and Infant were estimated for local hand-dug wells water sample. For Adult it was found that the excess life cancer risk for local hand-dug wells water sample varies from 8.35E-3 for sample point UM 21 as the lowest value to $6.45 \mathrm{E}-3$ for sample UM 15 as the highest values with mean value of 2.37E-1, for children the excess life cancer risk for local hand-dug wells water sample varies from 1.25E-3 for sample point UM 21 as the lowest value to $9.68 \mathrm{E}-3$ for sample UM 15 as the highest values with average value of 3.61E-3. For infant the excess life cancer risk for local hand-dug wells water sample. Varies from 1.46E-3 for sample point UM 21 as the lowest value to $1.13 \mathrm{E}-2$ for sample UM 15 as the highest values with mean value of $4.21 \mathrm{E}-3$.

Table 5. Revealed the Comparison of Annual Effective Doses from Ingestion from Dutse With Others Related Research within the country.

Table 5. Comparison of Annual Effective Doses from Ingestion and Inhalation from Dutse With Others Related Research.

\begin{tabular}{|c|c|c|c|c|}
\hline Locations & $\mathbf{E}_{\mathrm{A}}$ ing $\mathrm{mSvy}^{-1}$ & E $_{\mathrm{C}}$ ing $\mathrm{mSvy}^{-1}$ & E$_{\mathrm{I}}$ ing $\mathrm{mSvy}^{-1}$ & Source \\
\hline Sokoto & 0.25 & 0.37 & 0.43 & (Abba et al, 2020). \\
\hline Dutsinma & 0.47 & 0.94 & 3.30 & (Adams, 2017). \\
\hline Dutse & 0.69 & 1.03 & 1.20 & (Current study, 2021) \\
\hline Jos & 0.12 & - & - & (Aminu, 2020). \\
\hline
\end{tabular}

\section{DISCUSSION}

The ${ }^{222} \mathrm{Rn}$ concentration for water samples in Dutse Local Government, Jigawa state, Nigeria, were studied and analyzed. The study covered radon concentration, estimation of annual effective dose from ingestion for infant, children's and adult, estimation of excess life cancer risk due to ingestion for for infant, children's and adult. Also the annual effective dose were compared with other research within the country (Nigeria).

The mean ${ }^{222} \mathrm{Rn}$ concentration of all water samples were found to be $82.75 \mathrm{BqL}^{-1}$ and $94.11 \mathrm{BqL}^{-}$

1 for borehole and local hand-dug well water supply respectively. which is above the accepted 
value of $11.1 \mathrm{BqL}^{-1}$ as set by USEPA (1999), world average value of $10 \mathrm{BqL}^{-1}$ (WHO, 1993; UNSCEAR, 2002) and $11.1 \mathrm{BqL}^{-1}$ set by the (SON, 2003). But below the maximum concentration level as recommended by (EU 2001; WHO, 2008). The finding is slightly in accordance with study carried out by (Adams, 2017), who found mean radon concentration to be $64.66 \mathrm{BqL}^{-1}, 41.15 \mathrm{BqL}^{-1}$ and $34.57 \mathrm{BqL}^{-1}$ for Earth-Dam, open well and Borehole respectively. But not in accordance with study carried out by (Abba et al, 2020), who's found mean ${ }^{222} \mathrm{Rn}$ concentration to be $34 \pm 3.7 \mathrm{BqL}^{-1}$. The annual effective dose from ingestion for different age categories (Adult, children and infant) from the corresponding radon concentration for borehole and local hand-dug well water sample were ranged from 0.22797, $0.341954,0.39897 \mathrm{mSv} / \mathrm{y}$ to $1.9944855,2.991727,3.490348 \mathrm{mSv} / \mathrm{y}$ with mean value of 0.604047 , 0.90607, $1.057081 \mathrm{mSv} / \mathrm{y}$ in borehole water sample for Adult, Children and Infant respectively. And $0.2387,0358051,0.417726 \mathrm{mSv} / \mathrm{y}$ to $1.84295,2.764425,3.225163 \mathrm{mSv} / \mathrm{y}$. with the mean value of $0.686986,1.030479,1.202226 \mathrm{mSv} / \mathrm{y}$. in local hand-dug well water sample for (Adult, Children and Infant) respectively. All the values of the annual effective doses due to ingestion were found to be above the accepted value of 0.1 and 0.2 for Adult and Children as set by the (UNSCEAR, 2008; WHO, 2004 and EU, 1998).

Excess life cancer risk (ELCR) by ingestion for different age categories (Adult, children and infant) from the corresponding annual effective dose for borehole and local hand-dug well water sample varies from $(7.98 \mathrm{E}-4,1.20 \mathrm{E}-3,1.396 \mathrm{E}-3)$ to $(6.981 \mathrm{E}-3,1.0471 \mathrm{E}-2,1.222 \mathrm{E}-2)$. With mean value of (2.114 E-3, 3.171 E-3, 3.7 E-3) in borehole water sample for (Adult, Children and Infant) respectively. And (8.35 E-3, 1.253 E-3, 462 E-3) to $(6.45$ E-3, 9.675 E-3, 1.129 E-2) with mean value of (2.37E-1, 3.61E-3, 4.21E-3), in local hand-dug well water sample for (Adult, Children and Infant) respectively. All the mean value was below the world average of $2.9 \mathrm{E}-4$ (Ibikunle et al 2018), but were above unity.

\section{CONCLUSION}

Since the beginning of life on earth, environmental pollution has been a great threat to humanity. Therefore, it is natural for the public to be active and sensitive against all the pollutants causing threats to our lives. In this current study the mean ${ }^{222} \mathrm{Rn}$ concentration were found to be $82.75 \mathrm{BqL}^{-1}$ and $94.11 \mathrm{BqL}^{-1}$ for borehole and local hand-dug well water respectively, the mean annual effective dose for borehole and local hand-dug well water was found to be $0.60,0.91,1.06 \mathrm{mSv} / \mathrm{y}$ and $0.69,1.03,1.20 \mathrm{mSv} / \mathrm{y}$ for Adult, children and infant respectively. and excess life cancer risk from the corresponding annual effective dose for borehole and local hand-dug well water was found to be 2.114E-3, 3.171E-3, 3.7E-3 and 2.37E1, 3.61E-3, 4.21E-3 Adult, children and infant respectively. The result indicates that non-of the result was able to escape from the maximum concentration limit set by (UNSCEAR,1993; WHO, 2004) and 11.1 value set by Standard Organization of Nigeria (SON, 2003). However only $36.36 \%$ and $18.18 \%$ for borehole and local hand-dug well water was found to be below the (UNSCEAR, 2000) value of 4.0-40.0. the study shows that the value of ${ }^{222} \mathrm{Rn}$ concentration of borehole water sample is much lower than the value of $222 \mathrm{Rn}$ concentration of local handdug well water sample. The maximum amount of radon concentration was related to local hand-dug well water resources. This may be due to granitic rocks in studied area, and lack of air-water contact in well due to the deep of the well. As a conclusion, radon concentration in borehole and local hand-dug well water is high and not safe to drink and other domestic uses. 


\section{REFERENCES}

Abba, L, Nasiru, R, Garba, N. N. and Ahmed, Y. A, (2020). Assessment of Annual Effective Dose Due to Inhalation and Ingestion of Radon in Water Samples from the Cement Industrial Area of Sokoto, North-Western Nigeria. FUDMA journal of science Vol. 4 No., pp 615-619.

Adamoh Nojeeb Oyeyemi (2021) risk impact assessment of natural occurring radioactive materials (NORMS) from operation activities in uke gold mine in karu Nasarawa. Int. J. Environ. Sci. 11:493-508.

Adams S. (2017). Assessment of radon-222 in some selected water sources at dutsin-ma town, Dutsin-ma local government area, katsina state. FUDMA journal of science Vol. 6 No., pp $147-153$.

Aminu S. Z (2015), land use land cover changes in Dutse (1986-2014), Jigawa state, Nigeria.

(Master's thesis). Department of Geography, Faculty of Science Ahmadu Bello University, Zaria Nigeria.

Chifu E. Ndikilar, Shittu Abdullah, and Daniel K. Ayuba (2016). Determination of Radioactivity Concentration and Estimation of Annual Effective Dose for All Age Categories of Drinking Water Collected from Dutse Town, Nigeria. IOSR Journal of Applied Physics (IOSR-JAP) E-ISSN: 2278-4861.Volume 8, PP 13-22 www.iosrjournals.org.

Dankawu U.M, G. D Adamu, M. N Mahraz, J. N Benedict A. Yakubu and M. Uzair. (2021). Determination of Radon Concentration and The Annual Effective Dose Due Inhalation for Some Borehole and Well Water Supply in Dutse, Jigawa State Nigeria. Journal of Science, Technology, Mathematics and Education (JOSTMED), Vol. 16 pp 22-24

EU. (2001). (European Commission) Commission recommendation of 20th December 2001 on the Protection of the public against exposure to radon in drinking water. 2001/982/Euratom, L344/ 85. Official Journal of the European Commission.

EU. (1998). (European Commission) European drinking water directive 98/83/EC of 3rd

November 1998 on the quality of water intended for human consumption. Official J L 330. Official Journal of the European Commission.

Ibikunle, S. B., Arogunji, A. M. \& Ajayi, S. O. (2018). Characterization of radiation dose and Excess life cancer risk due to natural radionuclides in soil from some cities in South western Nigeria. Journal of forensic and Criminal Investigation, 10(4), 8.

Jong-Mi Lee, Guebuem Kim (2006). A simple and rapid method for analyzing radon in coastal and ground waters using a radon-in-air monitor Journal of Environmental Radioactivity $89219 e 228$ www.elsevier.com/locate/jenvrad.

Joseph M.J (2016). Iron removal from borehole water: a case study of kiambu town.

Khattak, N. U. M. A. Khan, M. T. Shah, M. W. Javed, (2011). Radon concentration in drinking Water sources of the Main Campus of the University of Peshawar and surrounding areas, Khyber Pakhtunkhwa, Pakistan J Radioanal Nucl Chem 290:493-505.

Nnaji, J. C; Igwe, O. U; Onyedim, K. M; Okafor, P (2019) Radioisotope and Metal Concentrations In Borehole Water Samples of Umuahia and Umudike, Nigeria. J. Appl. Sci. Environ. Manage. 23(7):1403-1409, https://www.ajol.info/index.php/jasem http://ww.bioline.org.br/ja.

NPC (1991). National Population Commission, (1991). Report of the National Commission on Population and Household Census, Jigawa State Office.

NPC (2006). National Population Commission, (2006). Report of the National Commission on Population and Household Census, Jigawa State Office

Nwankwo L. (2013). Determination of Natural Radioactivity in Groundwater in Tanke-Ilorin, Nigeria.

Shittu Abdullah, Chifu E. Ndikilar, A. B. Suleiman, Hafeez Y. Hafeez. (2016). Assessment of 
Heavy Metals and Radioactivity Concentration in Drinking Water Collected from Local Wells and Boreholes of Dutse Town, North West, Nigeria. Journal of Environment Pollution And Human Health, Vol. 4, No. 1, 1-8

Simon Adu, E.O. Darko, A.R. Awudu, O.K. Adukpo, G. Emi-Reynolds, M. Obeng, F. Otoo, A. Faanu, L.A. Agyeman, C.K. Mensah, F. Hasford, I.D. Ali, B.K. Agyeman and R. Kpordzro (2011). Preliminary Study of Natural Radioactivity in the Lake Bosumtwi Basin Radiation Protection Institute, Ghana Atomic Energy Commission,

SON, (2003). Standard Organization of Nigeria (Inorganic constituents for drinking water Quality).

UNSCEAR, (1993). United Nations Scientific Committee on the Effects of Atomic Radiation: Sources and effects of ionizing radiation, UNSCEAR report to the General assembly with Scientific annexes, Volume II. New York: United Nations;

UNSCEAR, (2000). Sources and effects of ionizing radiations. United Nations Scientific Committee on the Effects of Atomic Radiation, Report to the General Assembly, With Scientific annexes. United Nations sales publication E.00.IX.3 and E.00.IX.4. United Nations, New York.

UNSCEAR. (2002). (United Nations scientific committee on the effect of atomic radiation) "Sources and effects of ionizing radiation". Report to general assembly with annexes. United Nations New York: United Nations Sales Publications.

UNSCEAR, 2009. United Nations Scientific Committee on the Effects of Atomic Radiation Sources and effects of ionizing radiation". Report to general assembly with scientific Annexes. United Nations New York: United Nations Sales Publications.

UNSCEAR. (2008). (United Nations scientific committee on the effect of atomic radiation) "Sources and effects of ionizing radiation". Report to general assembly with scientific Annexes. United Nations New York: United Nations Sales Publications.

USEPA. (1991). (United States environmental protection agency) federal register 40 parts 141 and 142: National primary drinking water regulations; radionuclides: Proposed rule. U.S. Government Printing Office, Washington D.C. EPA/570/991/700.

USEPA, (1999). (United States environmental protection agency) Health risk reduction and cost Analysis for radon in drinking water. Federal Register, Washington D.C. 64(38), 9559. Washington

USEPA, (2012) (United States environmental protection agency) a citizen's guide to radon: the Guide to protecting our self and your family from Radon. EPA402/K-12/002.

WHO, (2008) World health organization guidelines for drinking water quality. Incorporating first And second Addenda 3rd ed. WHO press, Geneva. Switzerland.

WHO. (1993). World Health Organization. (1993). Guidelines for drinking-water quality. Vol.1, 2nd edn. World Health Organization, Geneva.

WHO. (2004). (World health organization) guidelines for drinking water quality (3rd ed., vol. 1). World Health Organization. 